\title{
9 Not so exceptional after all?
}

\author{
Nordic gender equality and \\ controversies linked to the \\ Convention on the Elimination \\ of All Forms of Discrimination \\ Against Women
}

Anne Hellum

In the 1970s, the Nordic countries were among the first in the world to pass general laws that prohibited gender discrimination and sought to promote gender equality. They also played an active role in the drafting of UN gender policies and the Convention on the Elimination of All Forms of Discrimination Against Women (CEDAW), which was enacted by the UN General Assembly in 1979. These legal achievements feature in the Nordic success story regarding gender equality in fields like politics, work, education and family life, both at home and abroad (see more about this development in Chapter 8 of this volume by Holst and Teigen). They are also central elements in the image of a Nordic gender-equality model, which is associated with strong state feminism ${ }^{1}$ accompanied by laws and policies that promote substantive equality in all areas. Gender-equality and anti-discrimination legal frameworks could thus have been part of a strong women-friendly regional brand.

It is therefore puzzling that, in many respects, the Nordic countries' equality and anti-discrimination laws and policies are lagging behind the dynamic developments that are taking place in international equality and anti-discrimination law, particularly CEDAW and European Union law (Nielsen, 2012; Hellum, 2013; Nousiainen and Pentikäinen, 2013; Svensson and Gunnarsson, 2018). The Nordic states' argument that legislation that would have the effect of making CEDAW and other conventions apply directly in national law would skew the balance between the judiciary and the parliament and as such undermine representative democracy has been termed the Nordic human rights paradox (Føllesdal and Wind, 2009; Skjeie, 2009; Langford and Schaffer, 2013; Bailliet, 2016). This argument can be seen as a breach with being international heavyweights on gender equality.

Since the 1980s, and through the increased internationalization and Europeanization of equality and anti-discrimination laws and policies, the image of Nordic gender-equality exceptionalism has been increasingly challenged. In a context where 189 states have ratified CEDAW, gender equality has become a legal principle to which most states ascribe. Yet, whereas they were 
among the first to initiate and ratify CEDAW, the Nordic countries have in later years resisted the CEDAW Committee's call for legislation that ensures that the Convention applies directly in national law and takes precedence when coming into conflict with national law. This chapter will describe this development by outlining how different images and legal representations of gender equality have travelled back and forth between the Nordic countries and the UN from the 1970s to the present, and what this might entail for branding the countries and region as champions of gender equality.

The empirical starting point is an examination of the CEDAW Committee's responses to the periodic state reports of Nordic countries. The overall focus is on contestations regarding the relationship between CEDAW and these Nordic countries' gender-equality and anti-discrimination laws. An in-depth study of how Norway has responded to critical comments from the CEDAW Committee is supplemented with an analysis of responses from Sweden, Denmark and Finland. The chapter shows how the homecoming of international equality and anti-discrimination standards that these countries support at the international level is often met with resistance at the national level. There is a mismatch between the image as gender-equal champions at home and the international critique of national law. A comparison between these Nordic countries' responses to the CEDAW Committee's critique shows that, unlike the other countries, Norway has to some extent changed its equality and anti-discrimination laws to bring them into line with the Committee's recommendations. An examination of public debates in Norway regarding the status of CEDAW in Norwegian law suggests that Norway's reputation as an international champion of women's rights and human rights is a factor that influences law and policy-making. Bringing the country's actions in line with the brand as a superpower on gender equality is seen as a factor that may have influenced this motivation.

\section{The trajectory of anti-discrimination law in the Nordic countries}

The Nordic countries' enactment of general gender-equality and antidiscrimination laws in the 1970s and 1980s signalled the start of a strategic shift from specific and programme-based to general and rights-based gender-equality strategies. ${ }^{2}$ Until that time, gender equality had been promoted through a combination of piecemeal abolition of laws and policies that constituted formal discrimination against women and political measures. A characteristic feature of the Nordic countries' approach to equality was the use of corporative agreements and programmes that involved the state, labour unions and women's organizations.

While all of the Nordic countries have had gender-equality and antidiscrimination laws in place since the 1980s, the histories, legal and political origins, designs and enforcement systems of their various legal frameworks 
vary. Combining both gender-neutralized and gender-specific elements, the 1978 Norwegian Gender Equality Act set out to promote gender equality and improve the position of women. In 2017, it was replaced by a single law, the Equality and Anti-Discrimination Act, that covered discrimination on grounds that included gender, sexual orientation, gender identity, pregnancy, care, ethnicity, disability and combinations of these factors so-called intersectional discrimination. The new act, which also combines both gender-neutralized and gender-specific elements, sets out to improve the position of women, minorities and people with disabilities. The Swedish Sex Equality Act of 1980 was replaced in 2009 by a single law, the Discrimination Act, that covered seven grounds of discrimination, but not combinations of these grounds.

Unlike Norway and Sweden, Finland and Denmark have maintained separate gender-equality acts. Finland's 1986 Act on Equality between Women and Men was a direct result of the country's ratification of CEDAW. A gender-neutralized act, however, was seen as the most appropriate means of promoting gender equality. In Denmark, the 1975 Act on Equal Pay and the 1978 Act on Equal Treatment in the Labour Market were the first acts that prohibited gender discrimination. In 2006, these two acts were merged into a single Act on Equal Treatment in the Labour Market. This was in 2009 replaced by the Equal Rights Act, which also applies in areas outside the labour market. Neither the Finnish nor the Danish acts provide protection against intersectional discrimination.

Through their inputs to the preamble to the Convention on the Elimination of All Forms of Discrimination Against Women, the Nordic countries promoted the ideal of a family model where men and women worked outside the home and shared responsibilities for care and housework at home. Indeed, Sweden prompted the inclusion of the 14th paragraph of the preamble, according to which the states parties to the Convention declare that they are 'aware that a change in the traditional role of men as well as the role of women in society and in the family is needed to achieve full equality between men and women' (Rehof, 1993: 40). This formulation was influenced by Swedish sociologist, politician and diplomat Alva Myrdahl and her efforts to work for both Swedish and international reforms where individual liberty (especially for women) went hand in hand with shared responsibility for children both between the parents as well as between the family and the community. Denmark, Finland and Norway followed Sweden and shared the aim of emphasizing the importance of 'the role of both parents in the family and the upbringing of children' embedded in the 14th paragraph of the preamble. Sweden stated that 'true equality between men and women could not be introduced by means of measures dealing exclusively with women: some measures aiming to bring about changes in the traditional role of men would be required' (Rehof, 1993: 56). The Nordic countries thus supplemented the gender-specific prohibition against discrimination 
'against women' in Article 1 of CEDAW with a gender-neutralized and symmetric conception of equality.

\section{Critiquing the champions}

Since ratifying CEDAW, the Nordic countries have regularly submitted periodic state reports to the CEDAW Committee that monitors states' compliance with the Convention (Byrnes, 2012; Hellum and Ikdah1, 2019). These reports describe the progress of their efforts to respect, promote and fulfil the rights of women to substantive equality and protection against all forms of discrimination. The CEDAW Committee reviews these reports and issues concluding observations, which form an assessment of the states' performance.

In its concluding observations on the reports from the four Nordic countries, the CEDAW Committee has expressed similar types of critiques regarding the shortcomings of the gender equality and anti-discrimination laws of each country. Below, we will take a closer look at three sets of criticisms that have set off controversies about the role of CEDAW in Nordic law. These controversies provide a window into changing external and internal gender images and the representation of gender equality as a hallmark of the Nordic states in general, and of Norway in particular.

The first set of contestations derive from the CEDAW Committee's requirement that states parties to the Convention facilitate the independent participation of women's rights organizations in the state reporting procedure. While the Nordic countries, through the provision of development aid, have provided economic support to enable women's rights organizations in the global South to participate in the state reporting procedure, such support was not given to Nordic women's organizations. This practice shows how CEDAW was initially viewed by the Nordic states as a tool to promote women's rights in the global South and not in the Nordic countries.

The second controversy derives from the CEDAW Committee's call for constitutional and statutory measures to ensure that the Convention takes precedence over national laws that come into conflict with the principle of gender equality expressed in the Convention. National resistance to this requirement epitomizes tensions between the Nordic image of gender equality as an overall national value and political and legal traditions based on strong state prerogatives and popular majoritarian democracy.

The third controversy illustrates the tense relationship between, on the one hand, the CEDAW Committee's call for gender-specific and intersectional equality and anti-discrimination laws and, on the other, the Nordic countries' strong emphasis on gender-neutralized and one-dimensional equality and anti-discrimination laws, as well as policies that are premised on the sociocultural notion of sameness. 


\section{The first controversy: why does civil society's ability to hold states accountable matter more in the South than in the North?}

The CEDAW Committee, like other human rights treaty bodies, requires that the states parties to the Convention facilitate the independent participation of national human rights institutions and civil society in the state reporting procedure. The CEDAW Committee has paid particular attention to the states parties' duty to include women's rights organizations. The aim of this requirement is to promote state accountability through a balanced procedure whereby civil society - particularly women's organizations from all parts of the world - has access to international law. Initially, as a part of their international gender policies, the Nordic states provided economic support to women's rights organizations in what were termed third world countries so that they could participate in the CEDAW Committee's scrutiny of their states' reports. In the Nordic countries, with their imagined gender equality, such support was not provided. This was due partly to the fact that CEDAW was viewed by Nordic policy-makers as a tool for women's development in the third world and partly to the state-feminist approach to equality, with its blurred boundaries between state and civil society.

Since the 1980s, CEDAW has constituted the backbone of the Nordic countries' rights-based international gender policies. While Denmark has been criticized by the CEDAW Committee for its lack of attention to CEDAW's role in development policies. Norway, Finland and Sweden have been commended for their promotion of women's human rights in their development cooperation activities. ${ }^{3}$ Initially, the Nordic countries saw lack of state transparency and accountability as a phenomenon that stood in the way of gender equality in third world countries. Supporting the competence of women in the third world to write independent shadow reports and participate in the state reporting process was thus a central part of Finland, Sweden and Norway's international gender-equality policies. An example is the 2007 Action Plan for Women's Rights and Gender Equality in Development Cooperation (Ministry of Foreign Affairs, Norway, 2007). Like the earlier Strategy for Women and Gender and Equality in Development Cooperation (Ministry of Foreign Affairs, Norway, 1997), it was anchored in CEDAW. In the Foreword to the Action Plan, Minister of Development Erik Solheim stated that

The Government wants Norway to be a fearless champion of women's rights and gender equality. Accordingly, the rights, participation and influence of women will be at the core of Norway's development cooperation efforts. Our aim is to ensure the realization of the rights of women that are set out in international human rights conventions.

(Ministry of Foreign Affairs, Norway, 2007: 7) 
The Action Plan saw human rights and democracy as mutually constitutive. It stated that Norway would use the CEDAW Committee's concluding observations on Norway's partner countries in development cooperation as the point of departure for dialogue and priority-setting. Civil society, particularly women's organizations, was identified as a key actor in development and democracy-building. By providing economic support to enhance the competence and capacity of women's organizations to write independent shadow reports and participate in CEDAW's state reporting procedure, the Action Plan set out to promote democracy in terms of accountability vis-à-vis national authorities.

The state reporting procedures in the Nordic countries were for a long time a different ball game. Initially, women's organizations were not given an opportunity to present independent reports but were consulted as part of the preparation of the state report. This state-feminist approach, characterized by a blurring of the boundaries between state and civil society, did not sit well with the CEDAW Committee's call for independent NGO participation. It also differed from the approach favoured within the international gender policy of the Nordic countries where independent NGO reporting was actively promoted.

The Norwegian case study shows how democratic flaws in the statefeminist policy were challenged by the CEDAW Committee, which insisted that Norwegian women's rights organizations be given economic support to write independent shadow reports and participate in the proceedings (Hellum, 2013: 604). ${ }^{4}$ An in-depth study of the participation of Norwegian women's organizations in the CEDAW reporting process between 1982 and 2008 reveals that that the participation of nongovernmental women's organizations in these processes was severely limited (Halsaa and Thun, 2010). The study also shows that, for the most part, comments from the women's organizations were not included as separate attachments to the state's CEDAW report but were incorporated within the report without any specific reference being made to the statements made by the actual organizations. ${ }^{5}$ In 2007, Norwegian women's organizations wrote their first shadow report to the CEDAW committee without state funding. ${ }^{6}$ Owing to this lack of funding, however, the women's organizations were unable to present their shadow report in the Committee's preparatory meeting in New York. The Norwegian shadow report was thus presented to the Committee by the Malaysian representative of the international network International Women's Rights Action Watch (IWRAW). In its concluding comments on Norway's seventh periodic report, the CEDAW Committee took notice of 'the absence of Norwegian NGOs at the session, apparently for lack of funding. ${ }^{7}$ In 2011, for the first time, 32 women's organizations coordinated by the NGO FOKUS received funding from the Ministry of Family and Equality to produce and present an NGO shadow report to the CEDAW Committee. In its concluding comments on Norway's eighth periodic report, the Committee commended 'the State party for its financial 
support of women's organizations (NGOs) for the finalization of a shadow report and for travelling expenses to both the pre-session working group and the session'. ${ }^{8}$

The Norwegian case reveals the disjuncture between the country's national and international gender policies. It suggests that the Norwegian state's self-image as a pioneer of gender equality stood in the way of critical scrutiny of democratic flaws in the existing state-feminist policy according to which women's organizations were regarded as an integrated part of a corporate political culture. Rather than seeing Norway as exceptional in the light of its high score on global gender indexes, the CEDAW Committee insisted that Norway follow the same standards for Norwegian women's organizations as it did for third world women in relation to the right to independent access to international law. The fact that the CEDAW Committee saw the state-feminist approach as depriving Norwegian women's organizations of the right to independent democratic participation drew the attention of international women's rights organizations such as the IWRAW. Such negative international attention was a factor that motivated Norway to change its practice in order to reassert its reputation as a promoter of gender equality at home and abroad.

\section{The second controversy: why do the Nordic states resist incorporation of CEDAW into national law?}

Through their ratification of CEDAW and other human rights instruments, all of the Nordic states have agreed to implement international standards of gender equality and non-discrimination in national law. Human rights principles such as the rights to equality, self-determination, integrity and dignity are values that are shared by different political parties, different civil society organizations, different branches of government and different schools of jurisprudence in the Nordic region. It is therefore a puzzle that most of the Nordic countries have resisted the CEDAW Committee's call to incorporate CEDAW into their domestic legal systems to make it directly applicable in national law. The reluctance of Sweden, Denmark and Norway to make CEDAW directly applicable in national law speaks to the ambiguous and contested relationship between gender equality and national identity in those countries. The Norwegian controversy over incorporation, however, shows how women's rights organizations and independent human rights institutions can use CEDAW's state reporting procedure as a means of accountability in ways that may result in change.

Article 2 of CEDAW requires all state parties to incorporate the Convention into their domestic legal systems to secure the enforceability of its provisions at the national level. In General Recommendation 28, the Committee urges 'those States parties in which the Convention does not form part of the domestic legal order to consider incorporation of the Convention to render it part of domestic law, for example through a general law on 
equality, in order to facilitate the full realization of Convention rights as required by article 2 '.

In its reviews of state reports from Sweden, Denmark and Norway, the Committee has repeatedly concluded that these countries have failed to ensure that the Convention prevails over national law. Finland's Constitution, which, unlike the constitutions of the other Nordic countries, states that binding human rights conventions apply directly in national law, is unproblematic. ${ }^{9}$ In its concluding comments on Sweden's seventh periodic report, which was followed up by a combined eighth and ninth report, the CEDAW Committee expressed concern that

the provisions of the Convention, even though largely respected, have not yet been fully incorporated into the domestic legal system of the State party and, as a result, are not directly applicable in the national courts. $^{10}$

In its concluding comments on Denmark's reports, the CEDAW Committee has repeatedly called for legal measures that ensure the full incorporation of CEDAW within national law. ${ }^{11}$ In its concluding comments on the country's eighth periodic report, the Committee expressed regret that

notwithstanding its previous recommendation (CEDAW/C/DEN/CO/7, para. 15), the State party decided in October 2014 not to incorporate the Convention into its national legal order. In that regard, the Committee is concerned that the State party's Supreme Court has ruled that nonincorporated treaties do not have the same status in national law as incorporated treaties. ${ }^{12}$

In its consideration of Norway's fifth and sixth periodic reports in $2003,{ }^{13}$ the CEDAW Committee expressed concern that CEDAW had not been incorporated into Norway's Human Rights Act and recommended that the act be revised to incorporate CEDAW. This recommendation, which was not followed up by the Norwegian state, was reiterated by the Committee in its concluding comments on Norway's eighth periodic report. ${ }^{14}$

The Nordic countries have responded in different ways to the CEDAW Committee's call for incorporation. Denmark's wholesale rejection is notable, while Sweden has expressed a political will during dialogue to address the remaining gaps in its incorporation of CEDAW's provisions within national law. ${ }^{15}$ Unlike these countries, after ten years of resistance, Norway decided to follow the CEDAW Committee's call for incorporation of CEDAW into national law. On 19 June 2009, almost 30 years after Norway's ratification of CEDAW, the Women's Convention and the Optional Protocol to the Convention were incorporated into Norway's Human Rights Act. According to Article 2 of that act, in cases of conflict between the Human Rights Act and other provisions of Norwegian law, the former takes precedence. 
In order to understand the process whereby incorporation of CEDAW was promoted, resisted and finally adopted by the Norwegian state, I will take a closer look at the different legal narratives that were invoked by various state and non-state actors at different stages of the debate over the issue, which lasted for ten years. These legal narratives highlight the different imaginaries about the relationships between gender, national law and international law that underlie national legal cultures and subcultures. The concept of a national legal culture refers to ideals that are shared by different state and nonstate actors. A broadly agreed notion is that human rights principles such as equality, freedom, dignity and integrity are cornerstones of national law. The concept of national legal subcultures refers to different understandings among legal scholars or branches of state administration of how international law should be interpreted and applied at the national level.

The first integration controversy was about national hierarches of laws. It began with the enactment of the Human Rights Act in 1999, according to which three international conventions would take precedence in the event of conflict between those conventions and other provisions of Norwegian law. These were the European Convention on Human Rights, the International Covenant on Civil and Political Rights, and the International Covenant on Economic, Social and Cultural Rights. ${ }^{16}$ The decision of the social-democratic Stoltenberg I government to exclude CEDAW, the Convention on the Rights of the Child and the International Convention on the Elimination of All Forms of Racial Discrimination from the Human Rights Act gave rise to a fierce debate. This debate was centred around two strands of arguments that constituted different legal subcultures within the national legal culture. State institutions like the Ministry of Justice and the state legal counsel argued that only the 'main' conventions were suitable for incorporation. CEDAW and other 'specialist' conventions were deemed unsuitable. They referred to the Human Rights Law Commission, which had introduced a distinction between 'main conventions' and 'special conventions' in 1993 (Norges offentlige utredninger, 1993). In this way, they invented a national human rights hierarchy within which, owing to their 'specialist' character, CEDAW, the Convention on the Rights of the Child and the International Convention on the Elimination of All Forms of Racial Discrimination were ranked lower than the 'main conventions'.

This position was criticized by state and non-state actors who argued that all human rights were equal and that, by excluding CEDAW, the $\mathrm{Hu}-$ man Rights Act established a gendered human rights hierarchy that was in conflict with Norway's international reputation as a promoter of women's rights at home and abroad. When the Human Rights Act was passed in 1999, a majority in the Norwegian parliament requested that the Stoltenberg I government incorporate CEDAW and the Convention on the Rights of the Child into Norwegian law 'within reasonable time'. ${ }^{17}$ Most state institutions and independent national human rights institutions such as the Ministry of Education, the Ministry of Children and Family, the Ministry of Foreign 
Affairs and the Gender Equality Ombud shared the view that, since women's rights and gender equality were core principles both in international and in Norwegian law, CEDAW should be incorporated. In spite of this, the Christian Democratic coalition government (Bondevik I) that replaced the Stoltenberg I government lent its ear to the Ministry of Justice and the state legal counsel. These actors were of the view that incorporation of CEDAW and other conventions in the Human Rights Act would undermine Norway's existing legal culture, which was founded on values such as clarity and predictability. The use of metaphors that associated CEDAW with specificity, inferiority, chaos and indecisiveness, as opposed to the clear and general character of the main conventions, speaks to the gendered character of the dominant national legal culture that on the surface appeared gender-neutral.

The second aspect of the integration controversy turned on notions of democracy. In 2003, in its review of Norway's fifth and sixth periodic reports, the CEDAW Committee noted that CEDAW had not been incorporated into the Human Rights Act and recommended that

the State party amend section 2 of the Human Rights Act (1999) to include the Convention and its Optional Protocol, which will ensure that the provisions of the Convention prevail over any conflicting statutes and that its provisions can be invoked in domestic courts. ${ }^{18}$

The same year, a new argument in the controversy was introduced in the report of the Power and Democracy Commission (Norges offentlige utredninger, 2003). The overall concern of the majority in the Commission was that the growing number of international treaties ratified by the Norwegian state curtailed parliamentary democracy. The minority in the Commission, however, argued that international human rights instruments like CEDAW constituted a tool for a fairer distribution of power and resources between women and men and, as such, a means of achieving greater democracy (Skjeie, 2003).

The arguments and concerns articulated by the majority in the Commission became a powerful tool in the hands of the Ministry of Justice and the state legal counsel. They argued that incorporation of CEDAW into the $\mathrm{Hu}-$ man Rights Act would skew the balance between the judiciary and the parliament and accordingly undermine representative democracy. On the basis of advice from these state actors, the Christian Democratic coalition government (Bondevik II) concluded that the rule of precedence, embedded in the Human Rights Act, should in future be restricted to very special cases in relation to incorporation of international conventions:

In the light of certain international bodies' dynamic interpretation of international law - going in directions beyond the scope of what the legislative branch of government at the time of incorporation reasonably 
could foresee - there is ample reason to emphasize the need to be as consistent as possible in relation to the incorporation of international treaties that have a binding effect. The government is of the view that rules giving international law precedence in the event of conflict with other Norwegian law should be used restrictively. ${ }^{19}$

The law and democracy argument breathed new life into the national hierarchy argument that had been rejected by the Norwegian parliament in 1999. Faced with a threat to national popular democracy, the Bondevik II government concluded that it was of the utmost importance to uphold the legal boundary between international and national law. The Ministry of Children and Equality therefore proposed that CEDAW should be incorporated into the Gender Equality Act and not be given precedence in the event of conflict with other provisions of Norwegian law. ${ }^{20}$ This proposal was met with criticism from actors like the Gender Equality Ombud, the Ministry of Foreign Affairs, the Norwegian Centre for Human Rights, the Institute of Women's Law and women's organizations. These actors were of the view that incorporation of CEDAW into the Human Rights Act would strengthen the position of women in law and society, and accordingly strengthen democracy. The Bondevik II government's proposal was approved by a Conservative majority in the Norwegian parliament in 2005, but was opposed by Labour, the Socialist Left Party and the Centre Party.

The third integration controversy was about national status. Could the resistance of the Norwegian state to putting CEDAW on an equal footing with other conventions affect its legitimacy as an internationally acclaimed women's rights champion? This question was invoked by non-state actors that included women's rights organizations and experts in the fields of women's, gender and equal rights studies who were in favour of incorporation.

A key concern in this debate was how the state's resistance to incorporation of CEDAW undermined Norway's efforts to be 'a fearless champion of women's rights and gender equality', as the 2007 Action Plan for Women's Rights and Gender Equality in Development Cooperation put it (Ministry of Foreign Affairs, Norway, 2007: 7). The legitimacy argument was directed at the announcement by the centre-left coalition government (Stoltenberg II) that, to protect national democracy, it needed to reconsider its political promise to incorporate CEDAW into the Human Rights Act. ${ }^{21}$ The government was publicly asked how its changed position would affect its legitimacy as a 'champion of human rights'. The disjuncture between CEDAW's low status in national law and the way in which Norway 'branded' itself as a champion of women's human rights on the international scene was thus brought to the public's attention, in part through a debate between the author and the Minister of Justice. ${ }^{22}$ In spring 2009, the Ministry of Justice and the government legal counsel were publicly criticized for their political resistance and lack of loyalty to the policy of the Stoltenberg II government regarding the incorporation of CEDAW in national law (see Andenæs, 2008; 
Hellum, 2008; Hellum et al., 2009). As a result, the government changed its position, and the Ministry of Justice sent out a White Paper recommending incorporation of CEDAW into the Human Rights Act, which was approved by the parliament. ${ }^{23}$ In his address to the Norwegian parliament, while affirming the centrality of the principle of gender equality as a national value, the minister of justice emphasized that this was the very last convention that would ever be incorporated into the Human Rights Act. ${ }^{24}$

These three aspects of the controversy over CEDAW's incorporation into national law speak to the tense relationship between the Norwegian state's identity as an international champion of women's human rights and the perception of international law as a threat to an 'imagined community' of original Nordic ethnicity. They show how a strong protection of women's human rights can coexist with a weaker protection of other groups, such as people with disabilities or ethnic minorities. A puzzle in this regard is how the internationalization of women's rights and gender equality, on the one hand, blurs the boundaries between Nordic and international law and, on the other, evokes nationalist feelings according to which CEDAW and other human rights conventions are perceived as an external threat to the imagined community of ethnic Nordic gender equality (Kantola and Nousiainen, 2009). This tension between changing laws and sociocultural perceptions suggests that the notion of gender equality in the Nordic countries in practice is premised on the notion that sameness between women and men and between majority and minority groups is necessary if different groups are to get along (Gullestad, 2001; Hellum, 2011).

\section{The third controversy: why are the Nordic countries resisting the CEDAW Committee's call for gender-specific anti- discrimination laws?}

Another contested issue is whether equality and anti-discrimination laws in the Nordic countries should be moulded on a gender-neutralized or a gender-specific legal design. A related issue is whether gender as a ground for discrimination should be constructed on the basis of a single identity or include protection against discrimination that is a result of interplay between gender and other grounds, such as ethnicity, sexual orientation, disability or age - so-called intersectional discrimination. CEDAW is a gender-specific convention that, according to Article 1, prohibits 'all forms of discrimination against women'. The CEDAW Committee, in its review of state reports, emphasizes that a gender-specific legal guarantee is necessary for combating the asymmetrical character of gender relations (Byrnes, 2012; Hellum and Ikdahl, 2019). Recognizing that discrimination of women on the basis of sex and gender is inextricably linked with other factors that affect women, such as race, ethnicity, religion or belief, health, status, age, class, caste, sexual orientation and gender identity, the CEDAW Committee also calls for legal protection against intersectional discrimination. In the following, I will explore tensions and conflicts between the Committee's call 
for gender-specific legislation that provides protection against intersectional discrimination and existing images and legal representation of gender in the Nordic countries.

The gender-neutralized design of most Nordic gender-equality and antidiscrimination legislation is premised on the view that gender equality is a matter of changing the roles of both women and men. To showcase this position, the Nordic states have over the last 15 years systematically selected male candidates to serve on the CEDAW Committee, the majority of whose members are female gender experts. As a result, the candidature of more competent female candidates has not been considered (Bailliet, 2016).

There are, however, tensions between this seemingly gender-neutralized and symmetric position and the CEDAW Committee's emphasis on the need to strengthen the position of women in order to achieve substantive equality.

In its review of the Nordic state reports, the Committee has emphasized the need for legislation that recognizes the skewed distribution of power and resources between women and men. Such concerns were expressed in the Committee's concluding comments on Denmark's eighth ${ }^{25}$ and Finland's fifth and sixth periodic reports. ${ }^{26}$ In its comments on Sweden's combined eighth and ninth periodic reports, the Committee clearly stated that it did not agree with Sweden's view that a gender-neutralized and single discrimination act was the best way of addressing gender discrimination. The Committee recommended that

the State party should also evaluate and, if necessary, revise the scope of protection of its Discrimination Act in order to ensure that it contains a definition of discrimination against women in accordance with article 1 of the Convention, covering inter alia, intersecting forms of discrimination. ${ }^{27}$

Another recurrent critique from the CEDAW Committee is that the onedimensional conception of gender discrimination that is prevalent in the Nordic gender-equality and anti-discrimination legislation is unsuited to addressing the discrimination challenges posed by increasing sociocultural diversity and transnationalism. ${ }^{28}$ In its consideration of Finland's sixth periodic report, the Committee stated that

the Gender Equality Act and the Non-Discrimination Act do not currently provide adequate protection to women against multiple or intersecting forms of discrimination. ${ }^{29}$

In line with this, the Committee urged the Finnish state to

ensure that reforms explicitly affording protection to women against multiple or intersecting forms of discrimination in all national gender equality and anti-discrimination laws are adopted in a harmonised manner. ${ }^{30}$ 
Unlike Sweden, Finland and Denmark, Norway has to some extent taken into consideration the CEDAW Committee's recommendations regarding the need for a gender-specific act that provides protection against intersectional discrimination. Norway's 2017 Equality and Anti-Discrimination Act replaces the Gender Equality Act of 2013. It is a single act that merges four specific anti-discrimination laws into one general equality and antidiscrimination act. The reform process, which was subject to several interventions by the CEDAW Committee, sparked off a series of controversies regarding the construction of gender equality and gender discrimination. The outcome of the process was an act whose aim was in line with CEDAW's call for a gender-specific legal guarantee. According to Article 1 of the 2017 Equality and Anti-Discrimination Act: 'This Act has the particular objective of improving the position of women and minorities.' Furthermore, Article 6 of the act provides protection against intersectional discrimination. The prohibition against discrimination in Article 6 includes discrimination on the basis of 'gender, pregnancy, leave in connection with childbirth or adoption, care responsibilities, ethnicity, religion, belief, disability, sexual orientation, gender identity, gender expression, age or combinations of these factors'.

CEDAW's state reporting procedure clearly fed into longstanding internal contestations regarding gender-specific, gender-neutralized and intersectional legal representations of gender in Norwegian equality and anti-discrimination law. The women's rights movement and the Equality Ombud have made systematic use of CEDAW's state reporting procedure as an arena in which to make different governments accountable for the proposed weakening of women's right to equality and non-discrimination. In the NGO shadow report commenting on Norway's eighth periodic report to the CEDAW Committee, women's organizations argued that the abolition of the Gender Equality Act would be

contrary to the obligation under the CEDAW, which requires dynamic action. Another consequence would be that differential treatment aimed at improving the status of women would be put on par with differential treatment aimed at improving the status of men. ${ }^{31}$

In her Supplementary Report to the Committee, the Equality Ombud commented:

If protection against discrimination on grounds of gender is incorporated in a new comprehensive Act without retaining the 'statement of purpose', the Ombud sees a danger that the work against discrimination of women can be weakened. A neutral statement of purpose in a comprehensive Act will obscure the fact that, as a society, Norway has not achieved full gender equality, and that discrimination has a gender perspective that still requires targeted efforts and measures aimed at improving the position of women in particular. ${ }^{32}$ 
In its concluding comments on Norway's eighth periodic report, the Committee noted the proposed abolition of the Gender Equality Act that set out to promote the position of women and expressed concern about

the use of gender-neutral legislation, policies and programs, which might lead to inadequate protection of women against direct and indirect discrimination and hinder the achievement of substantive equality of women and men. ${ }^{33}$

Against this background, and after a long public debate, the Conservative coalition government (Solberg II) decided to propose a single equality and anti-discrimination act with the specific purpose of improving the position of women, minorities and people with disabilities. It also decided to formalize existing practices in which the Equality Ombud, the Equality Tribunal and the lower courts provided protection against discrimination on a combination of grounds.

All in all, this picture of how the Nordic countries have resisted or adopted the CEDAW Committee's recommendations shows the contested terrain in which different gender images and legal definitions of gender equality travel back and forth between local, national and international legal arenas, and may be influenced by the imaging the countries in question wish to engage in of their own position on gender equality. Norway's adoption of a combined gender-neutralized and gender-specific act that provides protection against intersectional discrimination shows how national legal struggles may be influenced by the desire to maintain an international reputation as a promoter of women's human rights and gender equality. It should be borne in mind that, when the single equality act was passed in 2017, Norway's Prime Minister Erna Solberg was co-chairing with President Nana Addo Dankwa Akufo-Addo of Ghana the UN Secretary General's advocacy group for global goals - the Millennium Development Goals, followed by the Sustainable Development Goals.

\section{A Nordic equality model with five exceptions?}

An examination of the CEDAW Committee's reviews of Nordic state reports has shown that Nordic gender-equality legislation and practices in many instances fall short of international standards. Accordingly, the CEDAW Committee's concluding comments on the periodic reports of the Nordic states constitute a counter-narrative to the global gender indexes that through statistical ranking reproduce the external idea of the Nordic countries as havens of gender equality. An examination of the CEDAW Committee's concluding observations also reveals the disjuncture between the way in which the Nordic countries 'brand' themselves on the international scene and the different ways and degrees to which they resist full integration of international standards in their national laws. Accordingly, the CEDAW 
Committee's critical observations call the picture of the exceptional nature of the Nordic gender-equality model into question.

The diversity of approaches to national equality and anti-discrimination laws within the Nordic countries and their different responses to criticism from the CEDAW Committee also begs the question whether Nordic gender-equality laws, like the Nordic welfare model, should be seen as 'a model with five exceptions' (Christiansen et al., 2006). One puzzle in this context is why the CEDAW Committee, in spite of the strong resistance put up by powerful Norwegian state actors, has had greater impact on Norwegian legislation than in Sweden, Denmark and Finland. The outcome of the Norwegian CEDAW controversies, described in this article, suggests that international reputation and status are factors that under certain circumstances may influence national laws and policies concerning women's rights and gender equality.

\section{Notes}

1 The term 'state feminism' refers to cooperation between the women's movement and state authorities. The idea of the women-friendly Scandinavian welfare states was introduced by Norwegian political scientist Helga Hernes (1987).

2 For an overview of these developments in the Nordic countries, see Nordic Information on Gender (n.d.).

3 See CEDAW Concluding Comments on Denmark's fourth and fifth periodic reports, A/57/38, para. 321; CEDAW/C/FIN/CO/6, para. 165; CEDAW/C/SWE/ $\mathrm{CO} / 8-9$, para. 4.

4 In Sweden, the first independent NGO report was written in 2001 by two Swedish UN organizations on behalf of the country's women's organizations. The first state-supported NGO report was written by the Swedish Women's Lobby. In Finland, the first NGO report was written in 2004 and the second in 2008 (Nousiainen and Pentikäinen, 2013).

5 Norway's fifth periodic report, where comments from the Gender Equality Ombud, the Centre for Gender Equality, the MiRA Resource Centre for Black, Immigrant and Refugee Women, and the Women's Front were attached as an appendix, made an exception.

6 The report was a cooperation between FOKUS, Kompetanse- og ressurssenter i internasjonale kvinnespørsmål (Competence and Resource Centre for International Women's Issues), Kvinnesaksforeningen (the Norwegian Association for Women's Rights), Kvinnefronten (the Women's Front) and Internasjonal kvinneliga for fred og frihet (Women's International League for Peace and Freedom).

7 CEDAW/C/NOR/CO/7, para. 5.

$8 \mathrm{CEDAW} / \mathrm{C} / \mathrm{NOR} / \mathrm{CO} / 8$, para. 3.

9 Under Finland's Constitution, binding human rights conventions take direct effect in national law (Nousiainen and Pentikäinen, 2013).

$10 \mathrm{CEDAW/C/SWE} / \mathrm{CO} / 8-9$, para. 14.

$11 \mathrm{CEDAW} / \mathrm{C} / \mathrm{DEN} / \mathrm{CO} / 7$, para. 15

12 CEDAW/C/DNK/CO/8, para. 11.

13 CEDAW/C/NOR/5 and CEDAW/C/NOR/6, para. 21.

$14 \mathrm{CEDAW} / \mathrm{C} / \mathrm{NOR} / \mathrm{CO} / 7$, para. 14.

15 CEDAW/C/SWE/CO/8-9, para. 4.

16 Proposition to the Odelsting No. 3 (1998-1999).

17 Recommendation No. 51 (1998-1999) to the Odelsting, para 1. 
18 CEDAW/C/NOR/5 and CEDAW/C/NOR/6, para. 21.

19 Report No. 17 (2004-2005) to the Storting, 74-75.

20 Proposition to the Odelsting, No. 35 (2004-2005) 80.

21 This political promise was embedded in the socialist coalition government's political statement for the governing period of 2005-2009, the so-called Soria Moria Declaration of 2005.

22 See the debate between in the Norwegian daily newspaper Dagbladet between Anne Hellum (2007) and Minister of Justice Knut Storberget (2007).

23 Høyring - inkorporering av kvinnediskrimineringskonvensjonen i menneskerettsloven, Ministry of Justice, 7 November 2008.

24 Innst. O. nr. (Recommendation to the Odelsting) 115 (2008-2009).

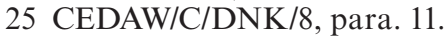

26 CEDAW/C/FIN/CO/6, para. 167.

27 CEDAW/C/SWE/CO/8-9, para. 15.

$28 \mathrm{CEDAW/C/SWE/CO/8,} \mathrm{para.} \mathrm{15;} \mathrm{CEDAW/C/DNK/8,} \mathrm{para.} 12$.

$29 \mathrm{CEDAW} / \mathrm{C} / \mathrm{FIN} / \mathrm{CO} / 7$, para. 10.

$30 \mathrm{CEDAW} / \mathrm{C} / \mathrm{FIN} / \mathrm{CO} / 7$, para. 11.

31 NGO Shadow Report to CEDAW 2011, Supplementing and Commenting on Norway's Eighth Periodic Report on the Implementation of CEDAW at 10.

32 The Equality and Anti-Discrimination Ombud's Report to the Pre-session of the CEDAW. A Supplementary Report on Norway's Eighth Official Report to the CEDAW Committee, p. 7.

33 CEDAW/C/NOR/C08, para. 8.

\section{References}

Andenæs M (2008) Interview with Mads Andenæs, Director of the Norwegian Centre for Human Rights. Klassekampen, 8 June.

Bailliet C (2016) A Nordic approach to promoting women's rights within international law: Internal v. external perspectives. Nordic Journal of International Law 85(4): 368-394.

Byrnes A (2012) CEDAW Article 1. In: Freeman M, Chinkin C and Rudolf B (eds) CEDAW Commentary. Oxford: Oxford University Press, 51-70.

Christiansen NF, Petersen K, Edling N and Haave P (eds) (2006) The Nordic Model of Welfare: A Historical Reappraisal. Copenhagen: Museum Tusculanum Press.

Føllesdal A and Wind M (2009) Nordic reluctance towards judicial review under siege. Nordic Journal of Human Rights 27(2): 131-142.

Gullestad M (2001) Imagined sameness: Shifting notions of us and them in Norway. In: Ytrehus LA (ed.) Forestillinger om 'den andre': Images of Otherness. Oslo: Norwegian Academic Press, 32-57.

Halsaa B and Thun C (2010) Partnering with the state? The role of women's organizations in governmental, CEDAW and CERD consultation processes. FEMCIT Working Paper No. 4. Oslo: Centre for Gender Research University of Oslo.

Hellum A (2007) Politisk spydspiss med sviktende legitimitet. Dagbladet, 8 March.

Hellum A (2008) Konvensjonell sexisme. Dagbladet, 12 June.

Hellum A (2011) The global equality standard meets Norwegian sameness. In: Hellum A, Ali SS and Griffiths A (eds) From Transnational Relations to Transnational Laws. Farnham: Ashgate, 71-93.

Hellum A (2013) Making space and giving voice: The CEDAW in Norwegian law. In: Hellum A and Aasen HS (eds) Women's Human Rights: CEDAW in International, Regional and National Law. Cambridge: Cambridge University Press, 588-625. 
Hellum A and Ikdahl I (2019). Committee on the Elimination of Discrimination Against Women (CEDAW). Max Planck Encyclopedia of International Procedural Law.

Hellum A, Skjeie H and Hernes H (2009) Om å holde ord. Dagbladet, 28 May.

Hernes H (1987) Welfare State and Woman Power: Essays in State Feminism. London: Norwegian University Press.

Holst C and Teigen M (2021) Silenced at the border: Norwegian gender-equality policies in national branding. In: Larsen E, Moss SM and Skjelsbæk I (eds) Gender Equality and Nation-Branding in the Nordic Region. Abington: Routledge, 153-172.

Kantola $\mathbf{J}$ and Nousiainen K (2009) Institutionalising intersectionality in Europe: Legal and political analyses. International Feminist Journal of Politics 11(4): 459-477.

Langford M and Schaffer JK (2013) The Nordic human rights paradox: Moving beyond exceptionalism. University of Oslo Faculty of Law Research Paper No. 2013-25. Available at: https://papers.ssrn.com/sol3/papers.cfm?abstract_id= 2275905\#\# (accessed 14 July 2020).

Ministry of Foreign Affairs, Norway (1997) Strategy for Women and Gender and Equality in Development Cooperation (1997-2005). Oslo: Ministry of Foreign Affairs.

Ministry of Foreign Affairs, Norway (2007) Action Plan for Women's Rights and Gender Equality in Development Cooperation 2007-2009. Extended for the Period 2010-2013. Oslo: Ministry of Foreign Affairs.

Nielsen R (2012) The impact of EU law on Scandinavian law in matters of gender equality. In: Nielsen R and Tvarnø CD (eds) Scandinavian Women's Law in the 21st Century. Copenhagen: Djøf Publishing, 63-90.

Nordic Information on Gender (n.d.) The Nordics: The Nordic gender effect at work. Available at: athttps://nikk.no/en/gender-equality-work-in-the-nordiccountries/ (accessed 6 January 2021)

Norges offentlige utredninger (1993) Lovgivning om menneskerettigheter. NOU 1993 : 18. Oslo: Departementenes servicesenter, Informasjonsforvaltningen.

Norges offentlige utredninger (2003) Makt og demokrati. NOU 2003: 19. Oslo: Departementenes servicesenter, Informasjonsforvaltningen.

Nousiainen K and Pentikäinen M (2013) Rise and fall of the CEDAW in Finland: Time to reclaim its impetus. In: Hellum A and Aasen HS (eds) Women's Human Rights: CEDAW in International, Regional and National Law. Cambridge: Cambridge University Press, 557-588.

Rehof LA (1993) Guide to the Travaux Preparatoires of the United Nations Convention on the Elimination of All Forms of Discrimination against Women. Leiden: Martinus Nijhoff.

Skjeie H (2003) Særuttalelse fra Hege Skjeie. In: Norges offentlige utredninger, Makt og demokrati. NOU 2003: 19. Oslo: Departementenes servicesenter, Informasjonsforvaltningen, 74-87.

Skjeie H (2009) Policy views on the incorporation of human rights conventions: CEDAW in Norwegian law. Nordic Journal of Human Rights 27(2): 260-271.

Storberget K (2007) Politisk kritikk med sviktende legitimitet. Dagbladet, 19 March. Svensson E-M and Gunnarsson $\AA$ (2018) Structuralism versus individualism in Swedish gender equality policy and law. NORA - Nordic Journal of Feminist and Gender Research 26(3): 230-237. 